\title{
Work Motivation among Malaysian Public Servants
}

\author{
Mahazril 'Aini Y. ${ }^{1}$, Zuraini Y. ${ }^{2}$, Hafizah H. A. K. ${ }^{3}$, Adnan Aminuddin ${ }^{1}$, Zaherawati Zakaria ${ }^{1}$, Nazni Noordin ${ }^{1}$ \& \\ Badrul Azmier Mohamed ${ }^{1}$ \\ ${ }^{1}$ Faculty of Administrative Science \& Policy Studies, Universiti Teknologi MARA, Merbok, Malaysia \\ ${ }^{2}$ Faculty of Accountancy, Universiti Teknologi MARA, Merbok, Malaysia \\ ${ }^{3}$ Faculty of Business Management, Universiti Teknologi MARA, Merbok, Malaysia \\ Correspondence: Zaherawati Zakaria, Faculty of Administrative Science \& Policy Studies, Universiti Teknologi \\ MARA, P. O Box 187, 08400 Merbok, Kedah, Malaysia. Tel: 60-4-456-2565. E-mail: \\ zaherawati@kedah.uitm.edu.my
}

Received: May 29, 2012 Accepted: June 7, 2012 Online Published: September 27, 2012

doi:10.5539/ass.v8n12p238 URL: http://dx.doi.org/10.5539/ass.v8n12p238

\begin{abstract}
Every organization is competing to survive in this ever increasingly challenging market environment. In order to survive, they need pools of excellent, talented and productive human capital to work in organization. With that, organizations need to provide public servants with suitable benefits such as a good salary, appreciations, good remuneration and other form of benefits. However, there is still a numbers of complaints received the public regarding poor service delivery especially from the counter services and front-line employees. In fact, an increasing number of complaints have been made the public due to delays by public sectors' employees in term of service delivery. This might happen due to the lack of work motivation and resulted in poor work performance. Therefore, this study aims to identify the factors that contribute to low work motivation and also to examine the relationship between motivational factors with employees' work motivation. Questionnaires constructed were distributed to 97 respondents from each divisions in Immigration Department. Besides, Descriptive statistics and Pearson Correlation were used in analyzing the data. The findings revealed that communication is the major factor that contributes to their low work motivation. In addition, motivated employees agreed that rewards and recognition and also communication may motivate them to work. In relation to this, recommendations have been made for future improvement and suggestions proposed for future research.
\end{abstract}

Keywords: low motivation, employees' motivation to work, public servants, rewards and recognition, work environment and communication

\section{Introduction}

Every organization is competing to survive in this ever increasingly challenging and volatile market environment. In order to survive, they need pools of excellent, talented and productive human capital to work in organizations. Due to this, organizations need to provide public servants with suitable benefits such as a good salary, appreciations, good remuneration and other form of benefits. With that, the employees themselves will be highly motivated in their jobs and this will lead to high performance in their work. Indirectly, this will help the organizations in competing and surviving in a challenging market environment.

In this current situation, not only the private sectors need to compete with others, but the public sector also needs to compete in this new challenging world. Due to this, the government has introduced Government Transformation Program (GTP) whereby under this program the government focuses on the improvement of public services in Malaysia (Government Transformation Programme, 2011). In Malaysia, the government has provided incentives such as salary increment and good remuneration system to ensure public servants are highly competent and motivated to do their jobs. It was introduced due to the complaints associated with lateness, rudeness and lack of job committed in service delivery, made by the public. This might happen due to the lack of work motivation and resulted in their low performance. In order to retain good employees in the organizations, it is important for organizations to design and offer good remuneration and compensation system as one way to motivate the employees to work because failure to motivate employees will affect not only individual but also the organizations as a whole. 
Work motivation is important in influencing people to energize their thinking, fuel enthusiasm and colour positive and negative emotional reactions (Clark, 2003). Motivation also generates mental effort that drives us to apply all our knowledge and skill into work. Without motivation, even the most capable person will refuse to work hard. Employees' motivation to work can be described as the psychological processes that direct, energize and maintain action towards a job, task, role or project (Kanfer, 1990). Work motivation is also understood as an employee's desire to work for the public interest (Perry and Wise 1990) and covers motives of employees in the public sector desiring "to do good for others and shape the well-being of society" (Perry and Hondeghem, 2008). In order to give the best output and excellent performance in workplace, employees need to be motivated to their jobs. Employees in both public and private sectors need motivational factors to motivate them to work.

\section{Literature Review}

In order to understand the factors that can motivate employees to work, the Immigration Department has been chosen as a case study for a better and clear understanding on what can motivate public servants to work. There are several contributing factors that influence employees' motivation to work. Rewards and recognition and also communication are among the factors identified by previous literatures. Rewards and recognition system is an important tool the management can use to channel employees' motivation in desired ways. In other words, reward systems seek to attract people to join the organization to keep them coming to work and motivate them to perform at high levels (Puwanenthire, 2011). Rizwan (2010) has conducted a study on the impact of rewards and recognition towards motivation stated that managers can provide recognition to employees by sitting with employees to have informal talks, spending time with them in form of a combined dinner or else in other activities like asking about their families and other crucial aspects related to their personal life. He also added that when effective rewards and recognition are practised within an organization, favourable working environment is produced that can motivate employees to excel in their performance. Other than that, a study from China University of Geosciences stated that money possesses significant motivating power as much as it symbolizes intangible goals like security, power, prestige, and a feeling of accomplishment and success (Faheem, Shuai, Mahroof and Mohsin, 2011). In contrast, the previous study conducted by Perry et al (2006) stated that financial rewards are not the most motivating factor. Several studies have found that, among employees surveyed, money was not the most important motivator to encourage them to work and in some instances managers have found money to have demotivating or negative effect on employees.

Other than rewards and recognition, communication is also one of the motivational factors that can motivate employees to work. Effective communication channels are also used in organizations to enhance the motivation of employees. The purpose of communication is to understand other people better. Managers can also stimulate motivation by giving relevant information, communicating with other employees and showing them good attitude. (Olajide, 2000). Positive perceptions around company communications serve to both boost motivation levels among current employees as well as foster employees' understanding of work (Wojtkowiak, 2009). Open communication will also make employees feel appreciated by organization thus making them loyal and retaining them in the organization. Thus, this situation will increase the level of work motivation among employees (Memmott and Growers, 2002).

\section{Methods}

This research used the quantitative method to identify the factors that motivate public servants to work. A Self-Administered Questionnaires had been developed and distributed to all employees in Immigration Department, Alor Setar, Kedah. 97 respondents among the total population have been chosen as the sample size based on Proportionate Stratified Random Sampling technique. The data collected from the questionnaires were analyzed using Statistical Package for Social Sciences (SPSS) version 16.0 software. Descriptive statistics is used to explain the factors that contribute to low work motivation among employees in the public sector. Besides, in order to test the hypothesis developed, Pearson Correlation is employed.

\section{Findings}

To analyse the relationship between motivational factors and employees' work motivation, the findings first outline the data on the level of employees' work motivation, followed by the discussion on the factors that contribute to low work motivation among employees in the public sector.

\subsection{Level of Employees Motivation to Work}

Table 1 shows the level of work motivation among employees in Immigration Department. Out of 97 respondents, $39(40.2 \%)$ of them experienced low work motivation However, findings also revealed that there 
are 34 employees who are highly motivated. This might happen because some of them were given Certificate of Appreciation as an appreciation for their work.

Table 1. Level of employees work motivation

\begin{tabular}{ccc}
\hline Level of Work Motivation & Frequency & Percent (\%) \\
\hline Low & 39 & 40.2 \\
Moderate & 24 & 24.7 \\
High & 34 & 45.1 \\
Total & 97 & 100 \\
\hline
\end{tabular}

\subsection{Factors That Contribute to Low Motivation to Work}

Table 2 shows the factors that contribute to low work motivation. The data are based on 39 respondents who rated themselves as having low motivation to work. Majority of the respondent consisting of 28 (71.8\%) viewed communication as the factor that contributes to low work motivation among them. In addition, another factor that contributes to low work motivation is work environment as agreed on by 27 respondents (69.3\%). Job assignment is also another factor which contributes to low work motivation and 25 respondents $(64.1 \%)$ agreed on this factor. In the Immigration Department, the lack of interaction in terms of meetings and discussion between employees and management leads to their low work motivation. Based on the findings, it can be concluded that communication contributes to low work motivation among employees in the public sector. This happens due to the lack of interaction between the public servants and management thus decreasing employees' motivation to work. Another factor that contributes to low motivation to work is the work environment. In the Immigration Department, the space is wide and comfortable, but there is no suitable decoration and this leads to employees lacking of enthusiasm to do their job.

Table 2. The factors that contribute to low motivation to work

\begin{tabular}{ccccccc}
\hline \multirow{2}{*}{ Variables } & \multicolumn{2}{c}{$\begin{array}{c}\text { Strongly } \\
\text { Disagree/Disagree }\end{array}$} & \multicolumn{2}{c}{ Neutral } & & \multicolumn{2}{c}{ Strongly Agree/Agree } \\
\cline { 2 - 7 } & $\begin{array}{c}\text { No. of } \\
\text { Respondent }\end{array}$ & \% & $\begin{array}{c}\text { No. of } \\
\text { Respondent }\end{array}$ & $\%$ & $\begin{array}{c}\text { No. of } \\
\text { Respondent }\end{array}$ \\
\hline Rewards and Recognition & 7 & 18.0 & 15 & 38.5 & 17 & 43.5 \\
Training and Development & 10 & 25.6 & 15 & 38.5 & 14 & 35.9 \\
Work Environment & 7 & 17.9 & 5 & 12.8 & 27 & 69.3 \\
Employee Participation & 7 & 17.9 & 9 & 23.1 & 23 & 59 \\
Communication & 7 & 17.9 & 4 & 10.3 & 28 & 71.8 \\
Job Assignment & 4 & 10.3 & 10 & 25.6 & 25 & 64.1 \\
\hline
\end{tabular}

4.3 The Relationship between Motivational Factors and Employees' Motivation to Work

Based on the data obtained from 34 respondents who rated themselves as having high level of work motivation, the researcher developed a hypothesis to determine if there is a relationship between the motivational factors and the employees' motivation to work in the Immigration Department Alor Setar, Kedah.

i) H1: There is a relationship between rewards and recognition with employees' motivation to work.

Table 3. The relationship between rewards and recognition and employees' motivation to work

\begin{tabular}{|c|c|c|c|}
\hline \multicolumn{4}{|c|}{ Correlations } \\
\hline \multirow{4}{*}{$\begin{array}{c}\text { Motivation to } \\
\text { Work }\end{array}$} & & Motivation to Work & Rewards and Recognition \\
\hline & Pearson Correlation & 1 & $.393^{* *}$ \\
\hline & Sig. (2-tailed) & & .024 \\
\hline & $\mathrm{N}$ & 34 & 34 \\
\hline
\end{tabular}


correlation indicate that there is a moderate relationship between rewards and recognition and employees' motivation to work as the Pearson correlation value 0.393, $\mathrm{r}=0.393$. Based on the analyzed result, the hypothesis is accepted since the significant value is less than 0.05 which is the significant value is $0.024, p<0.05$ $(p=0.024)$. This is because every employee needs rewards and recognition as one way to motive them to work. With rewards and recognition, they will put more effort in doing a job. Based on this study, the majority of respondents are age between 28 to 37 years old and considered as generation Y. As we know, Gen Y is more demanding, open and eager to get something (Julie Coates, 2007). Thus, they viewed rewards and recognition as one of the important factors to boost up their level of work motivation. This is supported by Rizwan (2010) in his study when he reported that when effective rewards and recognition are implemented within an organization, it can motivate employees to excel in their performance.

\section{ii) H1: There is a relationship between communications with employees' motivation to work.}

Table 4. The relationship between communication and employees' motivation to work

\section{Correlations}

Motivation to Work

Pearson Correlation

Sig. (2-tailed)

$\mathrm{N}$
1

34
Communication

$.390^{* *}$

.023

34

**. Correlation is significant at the 0.01 level (2-tailed).

It was hypothesized that a positive relationship would exist between these two variables. Results of the correlation indicate that there is a moderate relationship between communication and work motivation as the Pearson correlation value $0.390, r=0.390$. Based on the result that has been analyzed, the hypothesis is accepted since the significant value is less than 0.05 which is the significant value is $0.023, p<0.05(p=0.023)$. The findings indicate that communication leads to employees' motivation to work. Though communication is found to be the factors that contribute to low motivation to work in the Immigration Department, among the motivated employees, they agreed that regular meeting between employees and management such as monthly meeting can increase employees' motivation. In addition, the form of in which communication takes place can have a remarkable effect on the attitudes of employees and the degree to which they understand and support management policies. By referring to the past research, Wojtkowiak (2009) found that positive perceptions around company communications serve to both boost motivation levels among current employees as well as foster employees' understanding to work. It is further supported by Nzuve (1999) when his study indicates that communication can also be the best motivational factors in the organization because communication clarifies to employees what is to be done, how it is to be done, and what can be done to improve performance in the organization.

\section{Conclusion}

Based on overall discussion, result shows that communication is the factor that contributes to low work motivation among employees. Lack of meeting and face to face discussion between management and employees resulted in their low work motivation. Apart from that, work environment that is less attractive may decrease their motivation to work. In examining the relationship between motivational factors and employees' work motivation that consists of rewards and recognition and also communication, the finding shows that there is significant positive relationship between all motivational factors with employees' motivation to work. It revealed that all the variables are linked to employees' work motivation. Studies also suggest that the research can be conducted at other public sectors which deal with the public such as National Registration Department, Police Department, hospitals, schools and others public sectors to better know the level of their employees' motivation to work and develop the strategies in motivating the public servants in Malaysia.

\section{Recommendations}

Several recommendations have been made in helping the management to motivate the employees to work in Immigration Department of Alor Setar, Kedah. The management may improve the communication among the employees and the management. As communication is the major influencing factor which contributes to low work motivation among them, the management should be aware that communication is the important factor that can increase work motivation among their employees. The management of the Immigration Department may 
conduct frequent meetings that involve all employees, so that they can voice out their idea and be given the opportunity to communicate with their management. Moreover, group discussion may be practised, so that everyone can share their opinion and ideas. Other than that, the management may use other forms of communication such as using the social network like blogs, group face book or twitter to ensure that everybody can easily communicate with one another. With that, the employees and employer can exchange feedback and ideas. Another area for improvement is in term of their work environment. The management is suggested to make some improvement in order to keep employees motivated and contented with the surrounding by providing suitable decoration, keeping the environment clean and playing soft music in the office. Though all of the steps are relatively inexpensive ways to assist in the creation of a positive and professional work environment, it may help the organization to motivate the employees to perform better at their work.

\section{References}

Clark. (2003). Fostering The Work Motivation of Individuals And Teams. Performance Improvement, 42(3), 21-29. Retrieved from www.cogtech.edu/publications

Faheem Ghazanfar, Shuai Chuanmin, Mahroof Khan Muhammad, \& Mohsin Bashir. (2011). A study of relationship between satisfaction with compensation and work motivation. Retrieved from www.ijbssnet.com/journals/Vol._2_No._1;_January_2011/11.pdf

Government Transformation Programme. (2011). Retrieved from http://www.pemandu.gov.my/gtp/

Julie, C. (2007). Generational Learning Styles (1st ed.). LERN Books.

Kanfer. (1990). Work motivation: Past, present and future. Retrieved from http://www.management.wharton.upenn.edu

Memmott, \& Growers. (2002). Retaining and Motivating Employees. Washington Tree Fruit Postharvest Conference. Washington.

Olajide, A. (2000). Getting the Best out of the Employees in a Developing Economy. A Personnel Psychology Guest Lecture Series. Department of Guidance and Counselling, University of Ibadan, Nigeria.

Perry, \& Hondeghem. (2008). Motivation in Public Management: The Call of Public Service. Retrieved from www.ifigr.org/workshop/fall09/petrovsky.pdf

Perry, \& Wise. (1990). The Motivational Bases of Public Service. Retrieved from http://links.jstor.org/sici

Puwanenthiren. (2011). Reward System and Its Impact on Employee Motivation in Commercial Bank of Sri Lanka Plc, In Jaffna District. Retrieved from https://globaljournals.org

Rizwan. (2010). Impact of Reward and Recognition on Job Satisfaction and Motivation: An empirical study from Pakistan. Retrieved from www.ccsenet.org/ijbm

Wojtkowiak. (2009). Effective Communication Positively Impacts Employee Motivation Levels, Employee Advocacy Latest Ouch Point Survey From Opinion Research Corporation Suggests. Retrieved from www.opinionresearch.com 